\title{
The effects of systemic inflammatory response on prognosis of pancreatic ductal adenocarcinoma
}

\author{
Ali Aktekin ${ }^{1}$, Mehmet Torun ${ }^{1}$, Bala Basak Oven Ustaalioğlu², \\ Selvinaz Ozkara ${ }^{3}$, Ozcan Cakır ${ }^{4}$, and Tolga Muftuoglu ${ }^{5}$ \\ ${ }^{1}$ General Surgery Department, ${ }^{2}$ Medical Oncology Department, ${ }^{3}$ Pathology Department, and \\ ${ }^{4}$ Radiology Department, Haydarpasa Numune Education and Research Hospital, \\ ${ }^{5}$ General Surgery Department, Faculty of Medicine, Bahcesehir University, Istanbul, Turkey
}

\begin{abstract}
Backgrounds/Aims: The aim of this study was to investigate the prognostic significance of neutrophyil-lymphocyte ratio (NLR), platelet- lymphocyte ratio (PLR), CRP and CA19-9 in patients were diagnosed with pancreatic ductal adenocarcinoma (PDAC) to better verify pre-operative risk stratification and management. Methods: This retrospective study included data from 133 consecutive patients with PDAC, who were treated between 2013 and 2015. PDAC diagnosis was made by cytology or assumed by radiological assessment or surgical resection samples. All clinico-pathological data were retrieved from medical records at our institution. The laboratory data were obtained before any treatment modality. Dates of death were obtained from the central registry. Results: There was a statistically significant relation between radiological staging and CA19-9 and survival $(p=0.001, p=0.005)$ and there are significant differences in CA19-9 level between stage I and III, I and IV, II and III, and II and IV. Both CRP and CA19-9 levels were statistically significantly higher in patients with radiological lymph node metastasis than patients with N0 disease $(p=0.037$, $p=0.026)$. NLR and CA19-9 levels were also higher in metastatic disease $(p=0.032, p=0.007)$. According to Spearman's correlation analysis, we found in all patients that there was a negative correlation between the survival time and CRP and neutrophil count $(p=0.019, p=0.011)$. Conclusions: Preoperative CRP, CA19-9 and NLR are simple, repeatable, inexpensive and well available marker, can give information on lymph node and solid organ metastasis and survival, give clues to prognosis and be useful in clinical staging of patients with PDAC. (Ann Hepatobiliary Pancreat Surg 2019;23:155-162)
\end{abstract}

Key Words: Pancreas; Adenocarcinoma; Neutrophil; Lymphocyte; CRP

\section{INTRODUCTION}

Although cancer of pancreas has a low incidence of nearly $11 / 100.000$ person-years, it is the fifth most common cancer occurring today in humans. Moreover, it is the fourth among cancer caused deaths due to its poor prognosis rates. ${ }^{1}$ Only one fifth of patients are eligible for surgery at presentation. ${ }^{2}$ Predictability of patient subgroup with high early recurrence rate may be helpful in appropriate management of the disease. Knowing this information, appropriate time and type of surgical intervention may be selected along with neoadjuvant and adjuvant systemic chemotherapies.

Imaging techniques, such as endoscopic ultrasonogra- phy, computed tomography, and magnetic resonance imaging, are widely used in the evaluation of pancreatic ductal adenocarcinoma (PDAC) patients, however, their applications are limited because of their inconsistent sensitivity and specificity. ${ }^{3,4}$ Outcome of PDAC patients are routinely predicted by using conventional prognostic factors determined postoperatively. ${ }^{5}$ Therefore, although they are quite expensive, and are presented with technical problems, new potential preoperative prognostic indicators have been under investigation. Some new serum markers, such as MMP7, MUC1 and MUC2, have been proposed in evaluation of PDAC patients. ${ }^{6,7}$

Previous studies indicated that systemic inflammation of host might be helpful in estimation of clinical outcome,

Received: October 22, 2018; Revised: April 30, 2019; Accepted: May 2, 2019

Corresponding author: Ali Aktekin

Haydarpaşa Numune Eğitim ve Araştırma Hastanesi Tıbbiye Cad. No: 2334668 Üsküdar, Istanbul, Turkey

Tel: +90-5325987207, Fax: +90-216 54232 32, E-mail: draliaktekin@yahoo.com

Copyright (C) 2019 by The Korean Association of Hepato-Biliary-Pancreatic Surgery

This is an Open Access article distributed under the terms of the Creative Commons Attribution Non-Commercial License (http://creativecommons.org/ licenses/by-nc/4.0) which permits unrestricted non-commercial use, distribution, and reproduction in any medium, provided the original work is properly cited. Annals of Hepato-Biliary-Pancreatic Surgery • pISSN: 2508-5778 - elSSN: 2508-5859 
and interactions between tumor and host immune system independently, thus promoting tumor cell proliferation, metastasis, and activation of inflammatory cascade. ${ }^{8}$ Markers such as neutrophil/lymphocyte ratio (NRL), platelet/ lymphocyte ratio (PRL), and modified Glasgow prognostic score (mGPS) have been proposed to determine systemic inflammation in cancer patients. ${ }^{9,10}$ Although it has not been completely clear, some of potential preoperative prognostic indices may be serum C-reactive protein (CRP) levels, lymphocyte count, PLR and NLR in patients with PDA. ${ }^{10-12}$

In the present study, it was aimed to investigate prognostic roles of pre-operative inflammatory response (platelet, and lymphocyte count; NLR, PLR and serum CRP) in PDAC patients treated and followed-up in our surgery department.

\section{MATERIALS AND METHODS}

This retrospective study included data from 133 consecutive patients with PDAC, who applied to our institution between years 2013 and 2015. Patients, who were diagnosed with PDAC by cytology, or by surgical resection samples, or were assumed to have PDAC by radiological assessment, were included in this study. Rare histological subtypes, such as acinar cell carcinoma and neuroendocrine carcinoma were excluded from the study. All clinico-pathological data were retrieved from medical records at our institution. Tumor staging was performed according to the 7 th edition the TNM classification system. ${ }^{13}$ Laboratory parameters including neutrophil, and leukocyte counts, CRP and CA19-9 were measured before each treatment modality. Follow-up evaluations were performed every three months within the first three years, six months for five years and annually thereafter for curative resected tumors. The dates of death were obtained from the central registry. The study was approved by the local ethical committee with number of HNEAH-KAEK2016/ KK/94.

\section{Statistical analysis}

For comparison of normally distributed groups, Student's t test was used, whereas Mann Whitney U test was used for comparison of abnormally distributed groups. Nonparametric statistical methods were used for values with skewed distribution. For comparison of more than two normally distributed groups One-Way ANOVA test was used, whereas Kruskal Wallis test was used for comparison of more than two abnormally distributed groups. Non-parametric statistical methods were used for values with skewed distribution. The correlation between two abnormally distributed continuous variables was examined by Spearman Rho Correlation Coefficient.

Statistical analysis was performed using the MedCalc Statistical Software version 12.7.7 (MedCalc Software bvba, Ostend, Belgium; http://www.medcalc.org; 2013).

\section{RESULTS}

A total of 133 patients managed for PDAC were identified in database between years 2013 and 2015. There were 84 males and 49 females with the mean age of $67 \pm 10.6$ years (range 21-83). The mean survival time was $439.04 \pm$ 393.7. Totally there were 50 patients who underwent the operation. The biochemical and clinicopathological characteristics of the patients were shown in Table 1. Pancreas cancer was diagnosed generally in an advanced stage. Early stage disease was infrequent among both radiologically diagnosed as well as among the operated patients (radiological and pathological T1 was $2.3 \%$ vs $4.2 \%$, respectively). There was statistically significant relation between radiological staging and CA19-9 or survival $(p=0.001$ and $p=0.005$, respectively). According to the Post-Hoc binary comparisons, there are significant differences in CA19-9 level between stage I and III, I and IV, II and III, and II and IV. In addition to overall survival was significantly longer in stage I patients compared to stage III patients (Mann-Whitney, U $p<0.008$ Bonferroni correction) (Table 2).

CRP and also CA19-9 levels were statistically significantly higher in patients with radiological lymph node metastasis than in patients with N0 disease (Mann-Whitney $\mathrm{U}$ test; $p=0.037$ and $p=0.026$, respectively) (Table 3 ). NLR and CA19-9 levels were also higher in metastatic disease (Mann-Whitney U $p<0.05$ ) (Table 2).

Table 3 shows comparison of serum markers in respect to presence of lymph node metastasis on operated patient and there was no significant relation between blood parameters and N0 and N1 disease (Mann-Whitney U, Student $\mathrm{t} p>0.05)$. The comparison between pathological 
Table 1. Demographical characteristics of the patients and results of the blood parameters

\begin{tabular}{|c|c|c|c|c|}
\hline & & & Mean.. SD & (Median) Min.-Max. \\
\hline Age (year) & & & $67 \pm 10.6$ & (67) $43-92$ \\
\hline \multirow[t]{2}{*}{ Survial time (day) } & & & $439.04 \pm 393.7$ & (318) $10-1684$ \\
\hline & & & $\mathrm{N}$ & $\%$ \\
\hline \multirow[t]{4}{*}{ Gender } & Male & & 84 & 63.2 \\
\hline & Female & & 49 & 36.8 \\
\hline & Total & & 133 & 100.0 \\
\hline & & & Mean. \pm SD & Median (Min.-Max) \\
\hline CRP & & & $2.58 \pm 4.1$ & $1.2(0-31.9)$ \\
\hline Albumin & & & $2.9 \pm 0.7$ & $3(1.1-4.5)$ \\
\hline Neutrophil & & & $5593.2 \pm 2810$ & $4740(2090-19900)$ \\
\hline Lymphocyte & & & $1763.8 \pm 1107$ & $1630(290-10600)$ \\
\hline Platelet & & & $277707.5 \pm 102914$ & $256000(32100-620000)$ \\
\hline Neutrophil/Lymphocyte & & & $4.1 \pm 3.5$ & $3(0.8-20.9)$ \\
\hline Platelet/Lymphocyte & & & $193.4 \pm 119.8$ & $166.7(15.3-758.7)$ \\
\hline \multirow[t]{2}{*}{ CA $19-9$} & & & $13465.4 \pm 43892.1$ & $139(2-327000)$ \\
\hline & & & $\mathrm{N}$ & $\%$ \\
\hline \multirow[t]{14}{*}{ All patients } & Operabilities & Unoperated & 83 & 62.4 \\
\hline & & Operated & 50 & 37.6 \\
\hline & Radiological staging & 1 & 20 & 16.4 \\
\hline & & 2 & 39 & 32.0 \\
\hline & & 3 & 19 & 15.6 \\
\hline & & 4 & 44 & 36.1 \\
\hline & Radiological $\mathrm{T}$ & $\mathrm{T} 1$ & 3 & 2.3 \\
\hline & & $\mathrm{T} 2$ & 28 & 21.1 \\
\hline & & $\mathrm{T} 3$ & 51 & 38.3 \\
\hline & & $\mathrm{T} 4$ & 40 & 30.1 \\
\hline & Radiological N & No & 65 & 53.3 \\
\hline & & N1 & 57 & 46.7 \\
\hline & Radiological M & M0 & 78 & 63.9 \\
\hline & & M1 & 44 & 36.1 \\
\hline \multirow[t]{7}{*}{ Operated patients } & Pathological staging & 1 & 4 & 8.2 \\
\hline & & 2 & 45 & 91.8 \\
\hline & Pathological $\mathrm{T}$ & $\mathrm{T} 1$ & 2 & 4.2 \\
\hline & & $\mathrm{T} 2$ & 6 & 12.5 \\
\hline & & $\mathrm{T} 3$ & 40 & 83.3 \\
\hline & Pathological N & No & 17 & 34.0 \\
\hline & & N1 & 33 & 66.0 \\
\hline
\end{tabular}

CRP, serum C-reactive protein

T stage could not be performed because of p-value could not be calculated due to small number of pathological stage I $(n=4)$, pathological T1 $(n=2)$ and T2 disease $(n=6)$ (Table 3).

According to Spearman's correlation analysis, we found in all patient that negative correlation between survival time and CRP and neutrophil count (Spearman's rho, $p=0.019, p=0.011$ ) (Table 4).
When operated patients were compared to non-operated ones; CRP, CA19-9 levels were significantly higher among the group of non-operated patients. On the other hand, patients who underwent operation had longer survival than the metastatic patients (Mann-Whitney $\mathrm{U} ; p=0.007, p<0.001$, $p=0.001) \quad($ Table 5). 
Table 2. The comparision of the parameters according to radiological $\mathrm{N}$ and $\mathrm{M}$ levels and stages

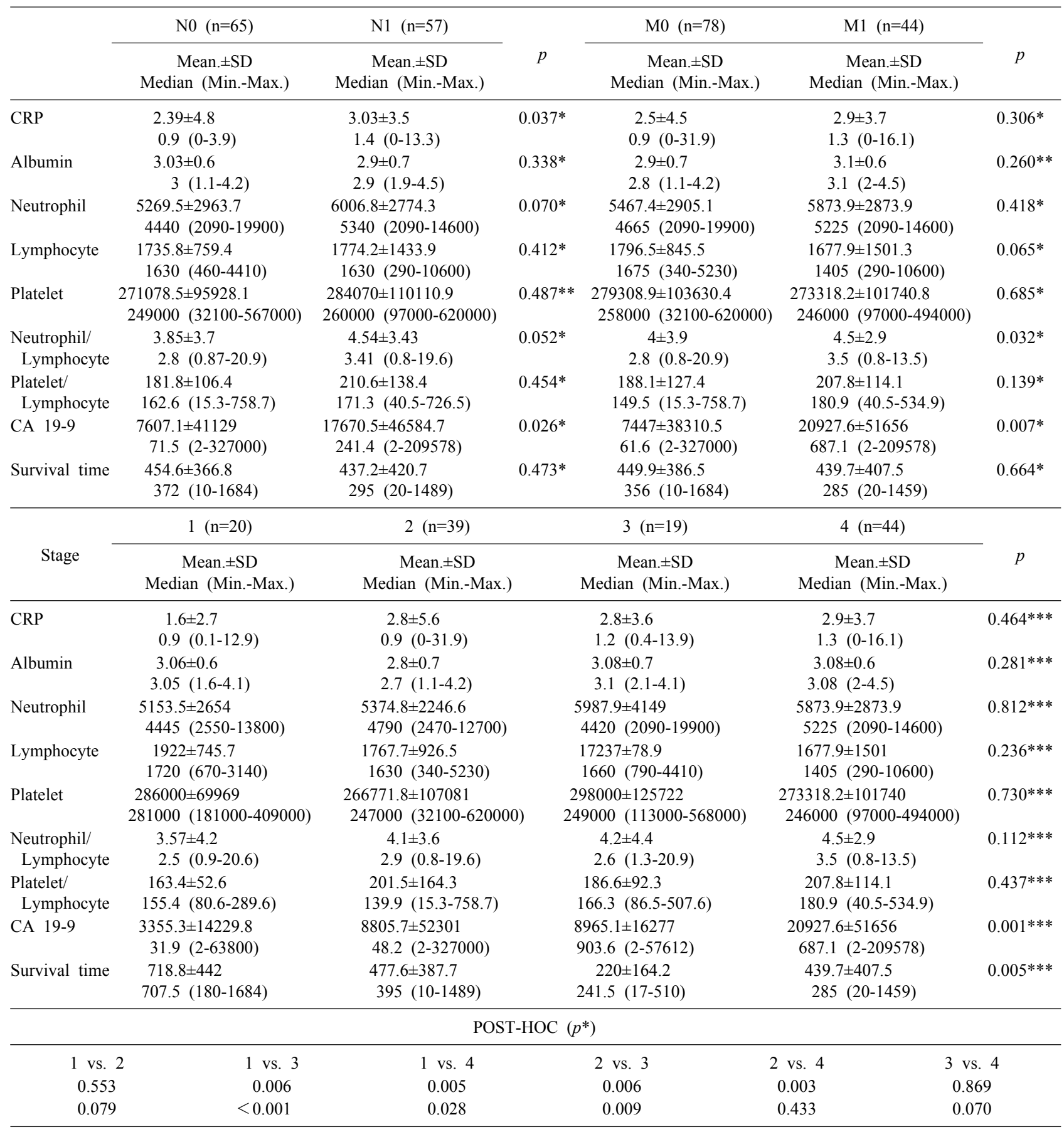

CRP, serum C-reactive protein

*Mann-Whitney $\mathrm{U} p$, **Student $\mathrm{t} p, * * *$ Kruskal Wallis $p$

\section{DISCUSSION}

In spite of increasing sophisticated imaging and staging techniques for PDAC, the unfavorable prognosis of PDAC cannot be improved. To optimize the management as surgery or systemic therapy planning, new prognostic and predictive factors are needed. Tumor burden and microenvironment modulate inflammatory response as a result in elevated inflammatory markers and effects on prognosis has been reported in various malignancies. ${ }^{14}$ Elevated CRP or NLR are independent prognostic indicator in resectable PDAC, and associated with the decreased median 
Table 3. The comparision of parameters according to pathological $\mathrm{N}$ stage

\begin{tabular}{|c|c|c|c|}
\hline & N0 $(n=17)$ & N1 $(n=33)$ & \\
\hline & $\begin{array}{c}\text { Mean. } . \text { SD } \\
\text { Median (Min.-Max.) }\end{array}$ & $\begin{array}{c}\text { Mean. } . \text { SD } \\
\text { Median (Min.-Max.) }\end{array}$ & $p$ \\
\hline CRP & $\begin{array}{l}0.84 \pm 0.6 \\
0.8(0-2.4)\end{array}$ & $\begin{array}{l}1.68 \pm 2.29 \\
0.8(0-129)\end{array}$ & $0.169 *$ \\
\hline Albumin & $\begin{array}{l}2.9 \pm 0.69 \\
3(1.1-4)\end{array}$ & $\begin{array}{l}2.9 \pm 0.6 \\
2.8(1.6-4.2)\end{array}$ & $0.638^{* *}$ \\
\hline Neutrophil & $\begin{array}{l}5084.7 \pm 1869.4 \\
4450(2530-9650)\end{array}$ & $\begin{array}{l}4901.8 \pm 2338.5 \\
4440(2470-13800)\end{array}$ & $0.455^{*}$ \\
\hline Lypmhocyte & $\begin{array}{l}1734.7 \pm 813.4 \\
1670(460-3140)\end{array}$ & $\begin{array}{l}1783.9 \pm 729.9 \\
1630(670-3280)\end{array}$ & $0.829 * *$ \\
\hline Platelet & $\begin{array}{l}288000 \pm 60129 \\
286000(181000-382000)\end{array}$ & $\begin{array}{l}268790 \pm 92487 \\
244000(32100-444000)\end{array}$ & $0.443 * *$ \\
\hline Neutrophil/Lymphocyte & $\begin{array}{l}3.78 \pm 2.69 \\
2.66(1.06-10.8)\end{array}$ & $\begin{array}{l}3.54 \pm 3.64 \\
2.78(0.87-20.6)\end{array}$ & $0.480 *$ \\
\hline Platelet/Lymphocyte & $\begin{array}{l}217.9 \pm 166.7 \\
171.2(80.6-758.7)\end{array}$ & $\begin{array}{l}175.1 \pm 95.2 \\
140.1(15.3-438.5)\end{array}$ & $0.467 *$ \\
\hline CA $19-9$ & $\begin{array}{l}367.7 \pm 725.3 \\
30.6(2-2281)\end{array}$ & $\begin{array}{l}12039 \pm 57614 \\
48.2(2-327000)\end{array}$ & $0.442 *$ \\
\hline Survival time & $\begin{array}{l}682.7 \pm 433.8 \\
386(332-1489)\end{array}$ & $\begin{array}{l}552.9 \pm 390.2 \\
485(10-1684)\end{array}$ & $0.519 *$ \\
\hline
\end{tabular}

CRP, serum C-reactive protein

*Mann-Whitney $\mathrm{U} p,{ }^{* *}$ Student $\mathrm{t} p$

Table 4. The results of correlation analysis on survivor

\begin{tabular}{|c|c|c|c|}
\hline & & $\begin{array}{c}\text { Survival time } \\
\text { (operated patients) }\end{array}$ & $\begin{array}{l}\text { Survival time } \\
\text { (all patients) }\end{array}$ \\
\hline \multirow[t]{3}{*}{ CRP } & $\mathrm{r}$ & 0.194 & -0.224 \\
\hline & $p$ & 0.249 & 0.019 \\
\hline & $\mathrm{n}$ & 37 & 110 \\
\hline \multirow[t]{3}{*}{ Albumin } & $\mathrm{r}$ & -0.183 & 0.123 \\
\hline & $p$ & 0.278 & 0.202 \\
\hline & $\mathrm{n}$ & 37 & 110 \\
\hline \multirow[t]{3}{*}{ Neutrophil } & $\mathrm{r}$ & 0.047 & -0.241 \\
\hline & $p$ & 0.781 & 0.011 \\
\hline & $\mathrm{n}$ & 37 & 110 \\
\hline \multirow[t]{3}{*}{ Lymphocyte } & $\mathrm{r}$ & -0.159 & -0.052 \\
\hline & $p$ & 0.348 & 0.588 \\
\hline & $\mathrm{n}$ & 37 & 110 \\
\hline \multirow[t]{3}{*}{ Platelet } & $\mathrm{r}$ & 0.175 & -0.062 \\
\hline & $p$ & 0.301 & 0.522 \\
\hline & $\mathrm{n}$ & 37 & 110 \\
\hline \multirow{3}{*}{$\begin{array}{l}\text { Neutrophil/ } \\
\text { Lymphocyte }\end{array}$} & $\mathrm{r}$ & 0.025 & -0.151 \\
\hline & $p$ & 0.882 & 0.115 \\
\hline & $\mathrm{n}$ & 37 & 110 \\
\hline \multirow{3}{*}{$\begin{array}{l}\text { Platelet/ } \\
\text { Lymphocyte }\end{array}$} & $\mathrm{r}$ & 0.183 & -0.008 \\
\hline & $p$ & 0.279 & 0.931 \\
\hline & $\mathrm{n}$ & 37 & 110 \\
\hline \multirow[t]{3}{*}{ CA 19-9 } & $\mathrm{r}$ & 0.080 & -0.176 \\
\hline & $p$ & 0.638 & 0.066 \\
\hline & $\mathrm{n}$ & 37 & 110 \\
\hline
\end{tabular}

CRP, serum C-reactive protein; Spearman's rho, $p<0,05$ survival, cancer-specific or disease-free survival. ${ }^{15}$ Sierzega et al. ${ }^{16}$ reported that NLR might indicate significant prognostic information for patients with resected PDAC, and concluded unfavorable prognosis, which was related to decreased number of immune cells effective against tumor, and increased cell population involved in immune suppression. The aim of this study was to review the evidence for CRP and NLR as prognostic indicators PDAC to determine their benefits in patient management.

In our study, we determined that both CRP level was statistically significantly higher in patients with radiological lymph node metastasis than in patients with N0 disease, and also NLR level was also higher in metastatic disease. Although it was not demonstrated in our study, PLR elevation was associated with worse survival in various solid tumors. The unfavorable prognosis might be correlated with decreased number of effective immune cells, and increased cell population causing immune suppression. ${ }^{17}$ Cheng et al. ${ }^{18}$ reported in their meta-analysis, which included 9 cohorts and 2035 patients, that NLR elevation predicted poor prognosis, and shorter overall survival in PDAC patients, and they concluded NLR elevation could be a predictor for poor survival in patients with pancreatic cancer with easy to access, and at a lower cost. 
Table 5. The comparision of parameters according to operabilities

\begin{tabular}{|c|c|c|c|}
\hline & Inoperable $(n=83)$ & Oparated $(\mathrm{n}=50)$ & \\
\hline & $\begin{array}{c}\text { Mean. } \pm \text { SD } \\
\text { Median (Min.-Max.) }\end{array}$ & $\begin{array}{c}\text { Mean. } \pm \text { SD } \\
\text { Median (Min.-Max.) }\end{array}$ & $p$ \\
\hline CRP & $\begin{array}{l}3.3 \pm 4.8 \\
1.3(0-3.9)\end{array}$ & $\begin{array}{l}1.4 \pm 1.9 \\
0.8(0-12.9)\end{array}$ & $0.007 *$ \\
\hline Albumin & $\begin{array}{l}3.03 \pm 0.7 \\
3.06(1.2-4.5)\end{array}$ & $\begin{array}{l}2.9 \pm 0.6 \\
2.8(1.1-4.2)\end{array}$ & $0.438^{* *}$ \\
\hline Neutrophil & $\begin{array}{l}5972.2 \pm 3084.1 \\
5170(2090-19900)\end{array}$ & $\begin{array}{l}4964 \pm 2172.6 \\
4445(2470-13800)\end{array}$ & $0.054 *$ \\
\hline Lymphocyte & $\begin{array}{l}1761.7 \pm 1279.9 \\
1630(290-10600)\end{array}$ & $\begin{array}{l}1767.2 \pm 751.4 \\
1630(460-3280)\end{array}$ & $0.434 *$ \\
\hline Platelet & $\begin{array}{l}279144.6 \pm 113797.5 \\
248000(97000-620000)\end{array}$ & $\begin{array}{l}275322 \pm 82772.9 \\
273500(32100-444000)\end{array}$ & $0.585^{*}$ \\
\hline Neutrophil/Lymphocyte & $\begin{array}{l}4.4 \pm 3.6 \\
3.2(0.8-20.9)\end{array}$ & $\begin{array}{l}3.6 \pm 3.3 \\
2.7(0.9-20.6)\end{array}$ & $0.051 *$ \\
\hline Platelet/Lymphocyte & $\begin{array}{l}195.7 \pm 117.8 \\
169.3(40.5-726.5)\end{array}$ & $\begin{array}{l}189.6 \pm 124.2 \\
155.4(15.3-758.7)\end{array}$ & $0.631 *$ \\
\hline CA $19-9$ & $\begin{array}{l}16714.7 \pm 4196.5 \\
608.9(2-209576)\end{array}$ & $\begin{array}{l}8071.4 \pm 46894 \\
40.4(2-327000)\end{array}$ & $<0.001^{*}$ \\
\hline Survival time & $\begin{array}{l}365.3 \pm 372.4 \\
250(17-1459)\end{array}$ & $\begin{array}{l}584.4 \pm 398.9 \\
485(10-1684)\end{array}$ & $0.001 *$ \\
\hline
\end{tabular}

CRP, serum C-reactive protein

*Mann-Whitney $\mathrm{U} p,{ }^{* *}$ Student $\mathrm{t} p$

In previous studies, it was reported that an increased neutrophil production was associated with higher proportions of immature cells, and an altered functional status promoting more aggressive growth of the tumor. It was reported that neutrophils had a role in angiogenesis, vascular invasion and metastasis. ${ }^{19}$ The cytokines involved in cancer-related inflammation, including interleukin-6 and tumor necrosis factor-alpha, para-neoplastic production of myeloid growth factors might induce neutrophilia. ${ }^{20}$ Elevated levels of tumor-infiltrating lymphocytes were reported to induce an effective anti-tumor cellular immune response in the primary tumor site. ${ }^{21,22}$ Neutrophils inhibit cytolytic ability of lymphocytes. ${ }^{23}$ Lymphopenia indicates disease and is related to the immune escape of tumor cells from tumor-infiltrating lymphocytes. ${ }^{24}$ As a result, elevated NLR generates an immune microenvironment promoting vascular invasion, and suppression of the host immune system. Additionally, monocytes can exert local immunosuppressive effects promoting tumor growth and angiogenesis. $^{25}$

CA19-9 is the most commonly used serum tumor marker for pancreatic cancer prognosis and treatment monitorization in PDAC. Its plasma level is dramatically increased during neoplastic disease. Since serum CA 19-9 level is associated with tumor burden of PDAC, patients with elevated CA 19-9 level may be at more advanced stage. ${ }^{26}$ In our study, there was a statistically significant correlation between radiological staging and CA19-9 or survival, and there were significant differences in CA19-9 level between stage I and III, I and IV, II and III, and II and IV. In addition, the CA19-9 levels were statistically significantly higher in patients with radiological lymph node metastasis and solid organ metastasis than patients with N0 disease. We highlighted again the preoperative CA 19-9 levels correlated with patient prognosis, and its serum levels were taken into account to decide respectability of PDAC.

Being an acute phase protein produced by the liver as part of the systemic inflammatory response, CRP has an important role in inflammatory processes and adaptive immune system. Tumor cells recruit endothelial cells, fibroblasts and inflammatory cells to shape their unique microenvironment, and results in a microenvironment enriched with proinflammatory cytokines and chemokines. ${ }^{27}$ The binding of CRP to phospholipids on tumor cells as an opsonin, augmenting tumor cell phagocytosis. ${ }^{28} \mathrm{~A}$ higher tu- 
mor stage can lead to a greater extend of systemic inflammation by release of tumor-degradation products, which in turn increase the CRP production in the liver. Elevated plasma CRP may represent a response secondary to tumor necrosis, and local tissue damage reflects a high tumor burden. $^{29}$ Thus, CRP may not only represent a response to tumor microenvironment, but also contribute to opsonization and elimination of tumor cells. In our study, CRP levels were statistically significantly higher in patients with radiological lymph node metastasis than patients with N0 disease. CRP levels were also significantly higher in patients with metastasis than non-metastasis, and there was a negative correlation between survival time and CRP. Similarly, Szkandera et al. confirmed the correlation between elevated CRP levels before management of PDAC, and decreased cancer specific survival of patients with PDAC. ${ }^{30}$ Pine et al. ${ }^{11}$ reported that increased plasma CRP concentration at the time of presentation of advanced PDAC carried a poor prognosis independently from biliary tract obstruction. As a result, CRP was a simple, repeatable, inexpensive and easily available marker showing a potential to select patients at high risk for poor clinical outcome for appropriate treatment strategies.

There are some limitations in our study; retrospective design and low quality. Patient cohorts were heterogeneous with regard to presence of associated inflammatory condition, and the use of anti-inflammatory medications. In addition, lymphocyte and monocyte subpopulations were not analyzed in our study, and we did not evaluate the functional status of immune cells.

Although these limitations, we found significant differences in CA19-9 level between stage I and III, I and IV, II and III, and II and IV in PDAC. In addition, both CRP and CA19-9 levels were statistically significantly higher in patients with radiological lymph node metastasis than in patients with N0 disease and NLR ratio and CA19-9 levels were also higher in metastatic disease. When patient who underwent operation due to radiological nonmetastatic disease were compared to ones who were not operated, low CRP but higher CA19-9 levels were determined. We also determined in all patients that there was a negative correlation between the survival time, CRP and neutrophil count. As a result, preoperative CRP, CA19-9 and NLR are simple, repeatable, inexpensive and easily available markers, which may well inform about lymph node and solid organ metastasis and survival and provide clues for prognosis and can be useful in clinical staging of patients with PDAC. However, high-quality studies and more multicenter prospective cohorts are required to validate the role of inflammatory mediators.

\section{REFERENCES}

1. Stevens L, Pathak S, Nunes QM, Pandanaboyana S, Macutkiewicz C, Smart N, et al. Prognostic significance of pre-operative C-reactive protein and the neutrophil-lymphocyte ratio in resectable pancreatic cancer: a systematic review. HPB (Oxford) 2015;17: 285-291.

2. Bilimoria KY, Bentrem DJ, Ko CY, Ritchey J, Stewart AK, Winchester DP, et al. Validation of the 6th edition AJCC pancreatic cancer staging system: report from the National Cancer Database. Cancer 2007;110:738-744.

3. Lan BY, Kwee SA, Wong LL. Positron emission tomography in hepatobiliary and pancreatic malignancies: a review. Am J Surg 2012;204:232-241.

4. Tseng DS, van Santvoort HC, Fegrachi S, Besselink MG, Zuithoff NP, Borel Rinkes IH, et al. Diagnostic accuracy of CT in assessing extra-regional lymphadenopathy in pancreatic and peri-ampullary cancer: a systematic review and meta-analysis. Surg Oncol 2014;23:229-235.

5. Raut CP, Tseng JF, Sun CC, Wang H, Wolff RA, Crane CH, et al. Impact of resection status on pattern of failure and survival after pancreaticoduodenectomy for pancreatic adenocarcinoma. Ann Surg 2007;246:52-60.

6. Moriya T, Kimura W, Hirai I, Takasu N, Mizutani M. Expression of MUC1 and MUC2 in ampullary cancer. Int J Surg Pathol 2011;19:441-447.

7. Wang SC, Parekh JR, Porembka MR, Nathan H, D'Angelica MI, DeMatteo RP, et al. A pilot study evaluating serum MMP7 as a preoperative prognostic marker for pancreatic ductal adenocarcinoma patients. J Gastrointest Surg 2016;20:899-904.

8. Mantovani A, Allavena P, Sica A, Balkwill F. Cancer-related inflammation. Nature 2008;454:436-444.

9. Stotz M, Gerger A, Eisner F, Szkandera J, Loibner H, Ress AL, et al. Increased neutrophil-lymphocyte ratio is a poor prognostic factor in patients with primary operable and inoperable pancreatic cancer. Br J Cancer 2013;109:416-421.

10. Smith RA, Bosonnet L, Raraty M, Sutton R, Neoptolemos JP, Campbell F, et al. Preoperative platelet-lymphocyte ratio is an independent significant prognostic marker in resected pancreatic ductal adenocarcinoma. Am J Surg 2009;197:466-472.

11. Pine JK, Fusai KG, Young R, Sharma D, Davidson BR, Menon $\mathrm{KV}$, et al. Serum C-reactive protein concentration and the prognosis of ductal adenocarcinoma of the head of pancreas. Eur $\mathbf{J}$ Surg Oncol 2009;35:605-610.

12. Clark EJ, Connor S, Taylor MA, Madhavan KK, Garden OJ, Parks RW. Preoperative lymphocyte count as a prognostic factor in resected pancreatic ductal adenocarcinoma. HPB (Oxford) 2007;9:456-460.

13. Exocrine and endocrine pancreas. In: Edge SB, Byrd DR, Compton CC, Fritz AG, Greene FL, Trotti A, ed. AJCC cancer staging manual. 7th ed. New York: Springer, 2010:241-249.

14. Krauthamer M, Rouvinov K, Ariad S, Man S, Walfish S, Pinsk I, et al. A study of inflammation-based predictors of tumor response to neoadjuvant chemoradiotherapy for locally advanced rectal cancer. Oncology 2013;85:27-32. 
15. Proctor MJ, Morrison DS, Talwar D, Balmer SM, Fletcher CD, O'Reilly DS, et al. A comparison of inflammation-based prognostic scores in patients with cancer. A Glasgow Inflammation Outcome Study. Eur J Cancer 2011;47:2633-2641.

16. Sierzega M, Lenart M, Rutkowska M, Surman M, Mytar B, Matyja A, et al. Preoperative neutrophil-lymphocyte and lymphocyte-monocyte ratios reflect immune cell population rearrangement in resectable pancreatic cancer. Ann Surg Oncol 2017;24: 808-815.

17. Moses K, Brandau S. Human neutrophils: their role in cancer and relation to myeloid-derived suppressor cells. Semin Immunol 2016;28:187-196.

18. Cheng H, Long F, Jaiswar M, Yang L, Wang C, Zhou Z. Prognostic role of the neutrophil-to-lymphocyte ratio in pancreatic cancer: a meta-analysis. Sci Rep 2015;5:11026.

19. Svennevig JL, Lunde OC, Holter J, Bjørgsvik D. Lymphoid infiltration and prognosis in colorectal carcinoma. $\mathrm{Br} \mathrm{J}$ Cancer 1984;49:375-377.

20. Teramukai S, Kitano T, Kishida Y, Kawahara M, Kubota K, Komuta K, et al. Pretreatment neutrophil count as an independent prognostic factor in advanced non-small-cell lung cancer: an analysis of Japan Multinational Trial Organisation LC00-03. Eur J Cancer 2009;45:1950-1958.

21. Dunn GP, Old LJ, Schreiber RD. The immunobiology of cancer immunosurveillance and immunoediting. Immunity 2004;21:137148.

22. Ropponen KM, Eskelinen MJ, Lipponen PK, Alhava E, Kosma VM. Prognostic value of tumour-infiltrating lymphocytes (TILs) in colorectal cancer. J Pathol 1997;182:318-324.

23. Petrie HT, Klassen LW, Kay HD. Inhibition of human cytotoxic $\mathrm{T}$ lymphocyte activity in vitro by autologous peripheral blood granulocytes. J Immunol 1985;134:230-234.

24. Ogino S, Nosho K, Irahara N, Meyerhardt JA, Baba Y, Shima $\mathrm{K}$, et al. Lymphocytic reaction to colorectal cancer is associated with longer survival, independent of lymph node count, microsatellite instability, and $\mathrm{CpG}$ island methylator phenotype. Clin Cancer Res 2009;15:6412-6420.

25. Lee HW, Choi HJ, Ha SJ, Lee KT, Kwon YG. Recruitment of monocytes/macrophages in different tumor microenvironments. Biochim Biophys Acta 2013;1835:170-179.

26. Wu L, Huang $\mathrm{P}$, Wang $\mathrm{F}$, Li D, Xie E, Zhang $\mathrm{Y}$, et al. Relationship between serum CA19-9 and CEA levels and prognosis of pancreatic cancer. Ann Transl Med 2015;3:328.

27. Miki C, Konishi N, Ojima E, Hatada T, Inoue Y, Kusunoki M. C-reactive protein as a prognostic variable that reflects uncontrolled up-regulation of the IL-1-IL-6 network system in colorectal carcinoma. Dig Dis Sci 2004;49:970-976.

28. Black S, Kushner I, Samols D. C-reactive Protein. J Biol Chem 2004;279:48487-48490.

29. McMillan DC, Canna K, McArdle CS. Systemic inflammatory response predicts survival following curative resection of colorectal cancer. Br J Surg 2003;90:215-219.

30. Szkandera J, Stotz M, Absenger G, Stojakovic T, Samonigg H, Kornprat $\mathrm{P}$, et al. Validation of C-reactive protein levels as a prognostic indicator for survival in a large cohort of pancreatic cancer patients. Br J Cancer 2014;110:183-188. 